\title{
KEDUDUKAN PEMIMPIN PEREMPUAN DALAM PERSPEKTIF HUKUM ISLAM
}

\author{
Widya Agesna \\ Program Studi Hukum Tata Negara IAIN Bengkulu \\ Jl. Raden Fatah Pagar Dewa Bengkulu \\ Email: agesnawidya@gmail.com
}

\begin{abstract}
Attempts to discuss women's leaders in Islam are the courage to enter a region full of the dangers of excessive generalization, excessive simplification, and restrictions that are almost inevitable from Western bias. The first problem is only one of the unresolved problems. Most of these factors are directly related to Islam itself, such as current and past legal reality, roles that are permitted and carried out as a result of Muslim images of women and religious ceremonies and diverse Islamic practices, where Muslim women have traditionally participated. Other supporting elements to provide a complete picture of women in Islam such as education, political rights, professional employment opportunities, and the like, have little to do with religion, but are still influenced by it. The issue of female leaders in Islam has often been discussed before, but until now the problem has not been eroded completely. This is inseparable from the factors that led to differences of opinion among the scholars, community leaders even in the community itself.
\end{abstract}

Keywords: Leader, Woman, Islamic Law

\begin{abstract}
Abstrak: Usaha untuk mendiskusikan tentang pemimpin perempuan dalam Islam merupakan keberanian untuk memasuki suatu wilayah yang penuh dengan bahaya generalisasi yang berlebihan, penyederhanaan yang berlebihan, dan pembatasan-pembatasan yang hampir tak terelakkan dari bias Barat. Persoalan pertama hanyalah merupakan salah satu di antara persoalan-persoalan yang belum terpecahkan. Kebanyakan dari faktor-faktor tersebut dihubungkan secara langsung pada agama Islam itu sendiri, seperti kenyataan hukum sekarang dan yang lampau, peran-peran yang diperbolehkan dan dijalankan sebagai hasil dari gambaran-gambaran orang Islam atas perempuan serta upacara keagamaan dan praktik-praktik Islami yang beragam, dimana perempuan-perempuan Muslim secara tradisional telah berpartisipasi. Unsur-unsur pendukung lain untuk memberikan gambaran yang utuh tentang perempuan dalam Islam seperti pendidikan, hak-hak politik, kesempatan kerja professional, dan yang sejenisnya, hanya sedikit berhubungan dengan agama, tetapi masih tetap dipengaruhi olehnya. Persoalan pemimpin perempuan dalam Islam memang sebelumnya sudah sering dibahas, akan tetapi sampai sekarang permasalahannya masih belum terkikis dengan tuntas. Hal tersebut tidak terlepas dari faktor-faktor yang menyebabkan terjadinya perbedaan pendapat dikalangan para ulama, tokoh masyarakat bahkan dalam masyarakat itu sendiri.
\end{abstract}

Kata Kunci: Pemimpin, Perempuan, Hukum Islam 
Widya Agesna:

Kedudukan Pemimpin Perempuan Dalam Perspektif Hukum Islam

\section{Pendahuluan}

Islam sebagai agama yang abadi adalah penutup semua agama. Karakteristik Islam di antaranya adalah menyeluruh dan moderat. Islam memberikan hak kepada setiap orang yang berhak menerimanya. Wanita tidak mendapat perlindungan sejak masa kecil sampai mati melainkan dalam naungan agama Islam.

Dalam hal-hal tertentu kedudukan perempuan dan laki-laki memang sudah setara. Bahkan saat ini kaum perempuan di Indonesia sudah leluasa untuk menentukan dan mengembangkan kariernya sesuai dengan keinginan dan kompetisinya. Dan sudah cukup banyak pos penting yang pernah dan sedang dipegang oleh kaum perempuan, seperti presiden, wakil presiden, menteri, hakim, anggota Dewan Perwakilan Rakyat, gubernur dan jabatan-jabatan penting lainnya.

Akan tetapi meskipun diskriminasi terhadap kaum perempuan mulai terkikis, namun masih saja belum sepenuhnya hilang. Walaupun dalam sejarah dunia telah muncul banyak wanita sebagai presiden dan perdana menteri di berbagai negara di seluruh dunia, di samping ratu di negara berbentuk kerajaan, sejumlah orang menganggap kurang cocok untuk menduduki posisi kepemimpinan tertentu. Bahkan dalam masyarakat tradisional, wanita masih ditolak untuk menjadi pemimpin. ${ }^{1}$

\section{Kedudukan Perempuan sebagai Pemimpin dalam Islam}

\section{Perempuan Boleh Menjadi Pemimpin}

Berkaitan dengan nilai kesetaraan dan keadilan, Islam tidak mentolerir adanya perbedaan atau perlakuan diskriminasi di antara umat manusia. Berdasarkan surah alAhzab ayat 35, yaitu :

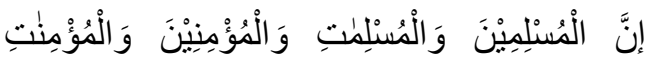

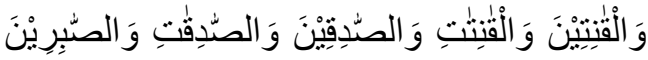

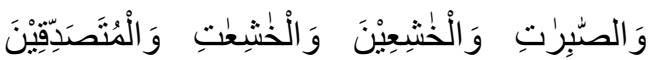

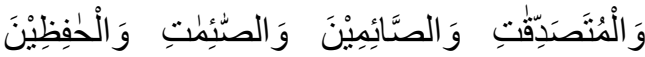

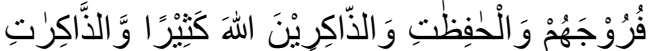

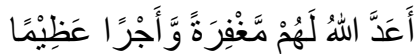

Artinya :

Sesungguhnya laki-laki dan perempuan yang muslim, laki-laki dan perempuan yang mukmin, laki-laki dan perempuan yang tetap dalam ketaatannya, laki-laki dan perempuan yang benar, laki-laki dan perempuan yang sabar, laki-laki dan perempuan yang khusyu', laki-laki dan perempuan yang bersedekah, laki-laki dan perempuan yang berpuasa, laki-laki dan perempuan yang memelihara kehormatannya, laki-laki dan perempuan

${ }^{1}$ Wirawan, Kepemimpinan : Teori, Psikologi, Perilaku Organiasasi, Aplikasi dan Penelitian, (Jakarta: PT Rajagrafindo Persada , 2013), h. 488 
yang banyak menyebut (nama) Allah, Allah telah menyediakan untuk mereka ampunan dan pahala yang besar. ${ }^{2}$

Dari ayat ini terlihat jelas bahwa Allah SWT. tidak membedakan antara lakilaki dan perempuan. Siapa saja diantara mereka akan mendapat ganjaran setimpal dengan apa yang telah mereka perbuat. Tidak ada perbedaan ataupun diskriminasi dalam hal ini. ${ }^{3}$

Mengenai boleh tidaknya perempuan jadi pemimpin, dapat dipahami menurut Abu Hanifah seorang perempuan dibolehkan menjadi hakim. Ketika perempuan diperbolehkan memberikan kesaksian dalam urusan harta, berarti memberikan keputusan dalam wilayah tersebut juga sudah semestinya diperbolehkan. Oleh karena itu seorang perempuan juga boleh menjadi pemimpin. ${ }^{4}$

Ketua Majelis Ulama Indonesia, Ma'ruf Amin, mengatakan bahwa MUI Pusat belum pernah mengeluarkan fatwa tentang larangan perempuan menjadi pemimpin. Kepemimpinan wanita baik di level pemimpin tingkat atas (imamat al udhma) ataupun tingkat bawah. Sebab, persoalan kepemimpinan perempuan termasuk masalah

2 Departemen Agama RI, Al-Qur'an dan Terjemahan, (Bandung : PT Syigma Examedia Arkanleema, 2010), h. 422.

3 Ratna Batara Munti, Perempuan Sebagai Kepala Rumah Tangga, (Jakarta: Lembaga Kajian Agama dan Gender, 1999), h. 38.

4 Imam Syawkani, Naiul Awtar, (Darul hadis, 1426 H / 2005 M), h. 592. yang diperselisihkan diantara ulama. "Terjadi perbedaan pendapat. Ada yang membolehkan dan ada yang melarang”. Sekalipun kelak dibahas di MUI, maka hasil akhirnya bisa dipastikan terjadi perbedaan. ${ }^{5}$

Ketua Umum DD, A. Muiz Kabri, mengungkapkan pada awalnya memang menganggap seorang perempuan tidak bisa menjadi presiden. Tapi belakangan ini, ia berpikir bisa saja seorang perempuan menjadi presiden. Karena bukan dia sendiri yang mengurusi negara. Presiden mempunyai banyak staf-staf yang membantu dalam mengurus permasalahan negara. ${ }^{6}$

Pendapat yang membolehkan perempuan menjadi pemimpin negara juga datang dari Ahmadiyah. Naib Amir Ahmadiyah Indonesia, H. Sayuti Azis, memandang tidak ada perbedaan antara perempuan dan laki-laki, karena dalam pandangan Allah perbedaan itu terletak pada ketaqwaan seseorang. Tidak ada masalah jika perempuan menjadi pemimpin negara. Hal ini menurut Sayuti adalah juga keputusan Ahmadiyah Pusat di London. Sebab, ketika terjadi pro-kontra tentang boleh-tidaknya perempuan menjadi kepala negara, Ahmadiyah Indonesia langsung meminta

5 News Republika, MUI tak Pernah Larang Pemimpin Wanita, diakses dari http://nasional.republika.co.id/berita/breakingnews/nasional/11/03/17/170321-mui-tak-pernahlarang-pemimpin-wanita, pada tanggal , 17 Maret 2011.

6 Jamhari, Ismatu Ropi, Citra Perempuan dalam Islam, (Jakarta: Gramedia Pustaka Utama, 2003), h. 123. 
fatwa dari London. Ternyata, pimpinan di sana tidak mempersoalkannya. Yang penting, calon presiden perempuan tadi memang benar-benar mempunyai kemampuan dan memenui persyaratan. ${ }^{7}$ Selain itu sudah cukup banyak pos penting yang pernah dan sedang dipegang oleh kaum perempuan, seperti presiden, wakil presiden, menteri, hakim, anggota Dewan Perwakilan Rakyat, Gubernur dan jabatan-jabatan penting lainnya. $^{8}$

\section{Perempuan Tidak Boleh Menjadi Pemimpin}

Walaupun dalam sejarah dunia telah muncul banyak perempuan sebagai presiden dan perdana menteri di berbagai negara di seluruh dunia, disamping ratu di negara berbentuk kerajaan, sejumlah orang menganggap kurang cocok utuk menduduki posisi jabatan kepemimpinan tertentu. Bahkan dalam masyarakat tradisional, wanita masih ditolak menjadi pemimpin. ${ }^{9}$

Mayoritas ulama yaitu Imam Syafi'i, Imam Malik dan Imam Ahmad berpendapat bahwa seorang pemimpin harus laki-laki begitu juga dengan presiden haruslah laki-

7 Jamhari, Ismatu Ropi, Citra Perempuan..., h. 126.

8 Djazimah Muqoddas, Kontroversi Hakim Perempuan pada Peradilan Islam di Negara-negara Muslim, (Yogyakarta: Lkis, 2011), h. xix.

Wirawan, Kepemimpinan : Teori, Psikologi, Perilaku Organiasasi, Aplikasi dan Penelitian, (Jakarta: PT Rajagrafindo Persada, 2013), h. 488 . laki berdasarkan surah an-Nisa' ayat 34 . Ditambah lagi dengan hadis dari Abi Bakrah yang diriwayatkan oleh Imam al-Bukhari, yang juga menjadi alasan yang dijadikan dasar bagi fatwa yang melarang perempuan menjadi pemimpin, yaitu ketika Nabi SAW. mendapatkan informasi bahwa bangsa persia menjadikan putri Kisra sebagai raja (ratu) mereka setelah Kisra meninggal dunia. Para ulama di semua negara Islam telah menerima hadist ini dan menjadikannya dasar hukum bahwa seorang wanita tidak boleh menjadi pemimpin laki-laki dalam wilayah kepemimpinan umum. ${ }^{10}$

Imam al-Baghawi mengatakan dalam kitab Syarhus-Sunnah bahwa seorang perempuan tidak sah menjadi seorang pemimpin. Karena seorang pemimpin itu harus keluar untuk berjihad dan selalu berada pada urusan atau perkara orang-orang Muslim. Sedangkan perempuan itu lemah serta tidak mampu melakukan banak urusan, karena perempuan itu kurang. ${ }^{11}$

Alasan lain yang melarang pencalonan wanita juga mengemukakan bahwa wanita itu menghadapi kendala yang sudah merupakan tabiat atau pembawaan mereka, seperti menstruasi setiap bulan beserta keluhan-keluhannya, mengandung

10 Yusuf Qardhawi, Fatwa-fatwa Kontemporer Jilid 1, (Jakarta: Gema Insani Press, 1999), h. 96

11 Abi Muhammad bin Mas'ud alBaghawi, Syarhus-Sunnah, ( Darul Kitab 'Amaliyah, 436-516 H), h. 322. 
AL-IMARAH: Jurnal Pemerintahan dan Politik Islam Vol. 3, No. 1, 2018

dengan segala penderitaannya, melahirkan dengan segala resikonya, menyusui dengan segala bebannya, dan sebagai ibu dengan segala tugasnya. Semua itu menjadikan mereka secara fisik, psikis, dan pemikiran tidak mampu mengemban tugas sebagai anggota dewan yang bertugas membuat undang-undang dan mengawasi pemerintah. $^{12}$

Persoalannya adalah, hingga saat ini tak banyak perempuan yang mau dan tertarik bergabung di dunia politik. Mereka beralasan karena image politik yang kejam, penuh pertarungan kekuasaan, sering kali dihinggapi kasus korupsi, dan sebagainya. Ini membuat sebagian besar perempuan memandang lemah diri dan kemampuannya karena melihat konstelasi politik sebagai hal yang menakutkan. Selain itu, image bahwa seorang pemimpin mesti tegar, berkuasa, kompetitif, rasional, mampu "mematikan" musuhnya (maskulinitas), membuat perempuan dan laki-laki menempatkan posisi ini memang pantasnya untuk laki-laki. ${ }^{13}$

\section{Perbedaan Pendapat mengenai Pemimpin}

\section{Perempuan}

\section{Perbedaan Penafsiran Ayat al-Qur'an}

Pendapat yang tidak membolehkan kaum perempuan menjadi pemimpin didasari

\footnotetext{
12 Yusuf Qardhawy, Fiqih Negara, (Jakarta: Robbani Press, 1999), h. 223.

${ }_{13}$ Ira D. Aini, Milastri Muzakkar, Perempuan Pembelajar, (Jakarta: PT. Elex Media Komputindo, 2014), h. 104.
}

oleh pemahaman tekstual terhadap ayat-ayat al-Qur'an yang secara subtantif telah memposisikan kaum laki-laki menjadi pemimpin bagi kaum perempuan. Kalangan fuqaha berendapat demikian mengacu kepada QS. an-Nisaa' ayat 34 yang berbunyi : ${ }^{14}$

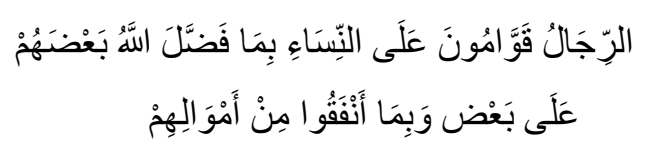

"Kaum laki-laki itu adalah pemimpin bagi kaum wanita, oleh karena Allah telah melebihkan sebahagian mereka (laki-laki) atas sebahagian yang lain (wanita), dan karena mereka (lakilaki) telah menafkahkan sebagian dari harta mereka." (Q.S. an-Nisaa' [4]: 34). ${ }^{15}$

Karena pertimbangan begitu sentralnya jabatan ini, maka para ulama klasik sepakat bahwa jabatan khalifah harus dipegang oleh lelaki berdasarkan surah an-Nisa' ayat 34 tersebut. Abu Ya'la al-Fara' menyebutkan salah satu persyaratan kepala negara harus memenuhi persyaratan menjadi hakim yang salah satu persyaratannya adalah lelaki. ${ }^{16}$

Sedangkan pendapat yang membolehkan pemimpin perempuan menjawab argumen pada firman Allah SWT. surah An Nisaa' ayat 34 tersebut. Berdasarkan asbab al-

${ }^{14}$ Hussein Muhammad, Fiqh Perempuan, (Yogyakarta: Lkis, 2001), h. 36.

${ }^{15}$ Departemen Agama RI, Al-Qur'an dan Terjemahan, (Bandung : PT Syigma Examedia Arkanleema, 2010), h. 84.

16 Ali Muhanif, Perempuan dalam Literatur Islam Klasik, (Jakarta: Gramedia Pustaka Utama, 2003), h. 132. 
nuzulnya, ayat ini turun berkenaan dengan kasus istri Sa'ad bin Rabi' yaitu Habibah binti Zaid bin Abi Zuhair, yang tidak taat kepada suaminya (nusyuz). Lalu Sa'ad menamparnya. Maka istri Sa'ad bersama ayahnya datang mengadu kepada Nabi Muhammad SAW. Ayahnya berkata, "Dia izinkan menikahi puteriku, tetapi kemudian ia menamparnya." Nabi Muhammad SAW. bersabda," suaminya mendapatkan hukum balas (qishas)." Ketika si wanita itu ingin kembali pulang bersama ayahnya hendak melaksanakan qishash pada suaminya.” Tibatiba Nabi SAW. bersabda: kembalilah, ini dia Jibil baru saja datang padaku menurunkan ayat ini "Kaum laki-laki itu pemimpin bagi kaum perempuan.” (Q.S. An-Nisa': 34). Selanjutnya beliau bersabda, "kami berkehendak akan suatu perkara, tetapi Allah SWT. berkehendak lain. Maka yang dikehendaki Allah itulah yang lebih baik. Lalu beliau memcabut qishash." 17

Jadi, ayat tersebut turun sebab khusus, yaitu berkenaan dengan kasus tertentu, masalah keluarga, dan tidak ada kaitan dengan keterlibatannya dengan kepemimpinan perempuan dalam hal politik.

\section{Perbedaan Penafsiran pada Hadist}

Terdapat hadis shahih ahad yang dari segi substansi matan haditsnya melarang

\footnotetext{
17 Al-Wahidi an-Nisaburi, Asbabun Nuzul; sebab-sebab turunnya ayat-ayat al-Qur'an, (Surabaya: Amelia, 2014), h. 230-231.

perempuan sebagai kepala negara yang diriwayatkan oleh Bukhari, Ahmad, Tirmidzi, dan An-Nasa'i dari Abu Bakrah r.a. lebih lengkapnya dapat dilihat pada terjemahan redaksinya sebagai berikut : Menceritakan kepada kami Usman bin alHaitsam, menceritakan kepada kita 'Auf dari Hasan dari Abi Bakrah ra, beliau berkata: Allah telah memberiku manfaat dengan kalimat yang aku dengar dari Rasulullah SAW. pada Perang Jamal setelah aku menganggap bahwa yang benar adalah pemilik unta (Aisyah ra) sehingga aku berperang di pihaknya. Kalimat yang aku dengar tersebut adalah ketika ada kabar yang sampai kepada Rasulullah SAW. bahwa penduduk Persia telah mengangkat anak perempuan Kisra sebagai raja mereka maka Nabi SAW. bersabda :

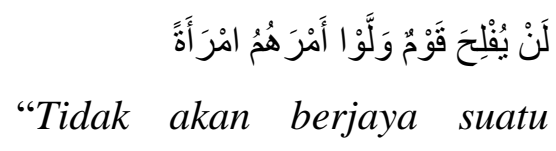
kaum yang menyerahkan urusan kepada perempuan.”(HR. Bukhari, Tirmidzi, dan An-Nasa'i). ${ }^{18}$

Jadi, yang dimaksud oleh hadits ini menurut Yusuf Qardhawy adalah larangan

\footnotetext{
${ }^{18} \mathrm{Abi}$ Muhammad bin Mas'ud alBaghawi, Syarhus-Sunnah, ( Darul Kitab 'Amaliyah, 436-516 H), h. 322. Imam Syawkani, Naiul Awtar, (Darul hadis, 1426 H / 2005 M), h. 591.
} 
AL-IMARAH: Jurnal Pemerintahan dan Politik Islam Vol. 3, No. 1, 2018

buat wanita untuk menjadi khalifah, pemimpin umum kaum muslim. ${ }^{19}$

Imam al-Syawkani mengatakan berdasarkan hadis yang telah disebutkan tersebut bahwa perempuan itu tidak ahli dalam hal pemerintahan dan tidak boleh suatu kaum menjadikan mereka sebagai pemimpin. Ibnu Jarir pun mengatakan bahwa pemikiran perempuan itu kurang dan tidak sempurna, terlebih lagi pada urusan laki-laki. Mushoni juga mengambil hadis yang telah disebutkan, ia mengatakan bahwa : jika dikatakan laki-laki dan laki-laki. Maka dapat dipahami bahwa perempuan tidak termasuk dalam hal ini. ${ }^{20}$

Kelompok yang membolehkan pemimpin perempuan pun menanggapi pada hadis Nabi Muhammad SAW., "Tidak akan berjaya suatu kaum kalau menyerahkan urusan kepada perempuan."

Asbab al-wurud (sebab turun) hadis tersebut bertalian dengan keputusan Ratu Kisra, Penguasa Persia, yang mengangkat anak perempuannya menjadi ratu, padahal waktu itu ia juga memiliki anak laki-laki, yang menurut cerita tidak disukainya. Disamping itu, Nabi Muhammad tidak melarang perempuan menjadi pemimpin. Ia hanya mengatakan tidak bahagia suatu kaum jika dipimpin oleh perempuan. Apalagi kalau

\footnotetext{
19 Yusuf Qardhawy, Fiqh Negara, (Jakarta: Robbani Press, 1997),h. 226.

${ }^{20}$ Imam Syawkani, Naiul Awtar, (Darul hadis, $1426 \mathrm{H}$ / $2005 \mathrm{M})$, h. 592.
}

didasarkan pada pilian like and dislike, sebagaimana kisa Ratu Kisra tadi. ${ }^{21}$

Menanggapi hadits tersebut, dari sudut metodologis, hadits itu dinyatakan sahih, tetapi dari segi periwayatan tergolong hadits ahad. Hukum hadis-hadis ahad tidak mendatangkan keyakinan ('ilmul-yaqin), melainkan hanya mendatangkan dengan kuat (zhann) saja. Oleh karena itu, tidak boleh bersandar pada hadis ahad dalam hukumhukum yang sangat penting. Terlebih lagi partisipasi perempuan dalam hak-hak politik dianggap sebagai masalah yang memiliki landasan konstitusional yang mencakup larangan dan kepentingan. ${ }^{22}$

\section{Berdasarkan Ijma}

Pendapat yang tidak membolehkan pemimpin perempuan ini pun didasarkan pada ijma untuk menguatkan pendapat tersebut dan mengatakan bahwa hal itu sudah dipraktekkan pada beberapa masa. Atau setidaknya pada masa Rosulullah SAW. dan masa Khulafaur Rasyidin yang berlaku tanpa kesertaan perempuan dalam kehidupan politik negara. Kendati ada sejumlah besar kaum perempuan yang terlibat di bidang budaya dan intelektual pada masa awal Islam, seperti istri-istri Nabi Muhammad SAW., tetapi mereka tidak berpartisipasi dalam masalah-masalah kenegaraan. Mereka

\footnotetext{
21 Jamhari, Ismatu Ropi, Citra Perempuan..., h. 125.

22 Ira D. Aini, Milastri Muzakkar, Perempuan Pembelajar..., h. 98.
} 
pun tidak diminta untuk berpartisipasi dalam masalah itu. ${ }^{23}$

Sedangkan, pendapat yang membolehkan pemimpin perempuan memandang tidak demikian. Pada kenyataannya, hal itu tidaklah benar. Jelas-jelas Rasulullah SAW. mengajak kaum perempuan bermusyawarah tentang berbagai hal.

Setiap mujtahid mengemukakan pendapatnya yang jelas dan semua sepakat terhadap ketentuan hukum dalam masalah tersebut. Oleh karena itu, tidak dapat dikatakan adanya ijma sharih ataupun sukuti yang melarang perempuan menggunakan hak-hak politik. ${ }^{24}$

\section{Berdasarkan Qiyas}

Dalam bersandar pada qiyas, para pencetus pendapat yang tidak membolehkan pemimpin perempuan ini melihat perbedaan antara laki-laki dan perempuan. Oleh karena itu, memungkinkan dilakukan qiyas dalam hal itu. Di antara contoh-contohnya adalah :

a. Tidak adanya perempuan untuk menjadi pemimpin bagi masyarakat umum dalam sholat lima waktu, sholat Jum'at, dan sholat Id.

23 Ikhwan Fauzi, Perempuan dan Kekuasaan; Menelusuri Hak Politik dan Persoalan Gender dalam Islam, (Jakarta: Amzah, 2008), h. 59.

24 Ikhwan Fauzi, Perempuan dan Kekuasaan..., h. 60.
b.Perempuan tidak mempunyai hak menentukan talak yang ditetapkan syariat melekat pada laki-laki, bukan pada perempuan.

c. Perempuan tidak boleh bepergian sendiri tanpa disertai muhrimnya atau teman yang dipercaya.

d.Perempuan tidak diwajibkan sholat Jum'at dalam jama'ah. Sebab dalam hadis disebutkan : "Sholat Jum'at diwajibkan kepada setiap Muslim secara berjamaah kecuali empat orang, yaitu hamba sahaya, perempuan, anak kecil, dan orang sakit." 25

Kelompok yang membolehkan pemimpin perempuan mengatakan, mengingat bahwa perempuan tidak punya hak talak, tidak boleh ditegaskan dalam ijma. Akan tetapi, dalam kaitannya dengan hukum yang ditegaskan dengan ijma, para ulama berbeda pendapat apakah boleh diqiyaskan masalah lain padanya atau tidak. Yang berkaitan dengan hukum syariat yang ditegaskan dengan teks Alqur'an, maka hukum-hukum ini semua hanya disebutkan dalam teks-teks yang menetapkan prinsip-prinsip umum tanpa penjelasan terhadap hal-hal parsial. Demikian pula halnya dalam pelaksanaan hukumhukum konstitusional yang berdiri sendiri. Ia bersumber pada aspek-aspek khusus (parsial) dan tidak dianggap sebagai syariat yang

25 Ikhwan Fauzi, Perempuan dan Kekuasaan..., h. 64. 
AL-IMARAH: Jurnal Pemerintahan dan Politik Islam Vol. 3, No. 1, 2018

umum. Pada gilirannya, tidak boleh menggunakan qiyas dalam hal itu. Secara umum dapat dikatakan secara ringkas bahwa tidak boleh menggunakan qiyas dalam hukum-hukum konstitusional. Sebab, hal itu termasuk bidang-bidang yang hanya ditetapkan melalui ijtihad. ${ }^{26}$

\section{Faktor Budaya}

Masih dijumpainya praktik marjinalisasi peran perempuan dalam kehidupan sosial kita agaknya berakar pada masih dominannya

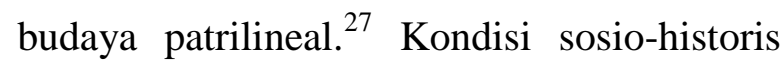
dan budaya pada masa sebelum dan awal datangnya Islam menunjukkan adanya suatu hegemoni budaya patriarki, yang mana kaum laki-laki lebih tinggi daripada kaum perempuan. $^{28} \quad$ Budaya patriarki memposisikan perempuan pada peran-peran domestik seperti peran pegasuhan, pendidik dan penjaga moral. Sementara itu, peran lakilaki sebagai kepala rumah tangga, pengambil keputusan, dan pencari nafkah. Perpanjangan dari berbagai peran yang dilekatkan pada perempuan tersebut maka, arena politik yang sarat dengan peran pengambil kebijakan terkait erat dengan isu-isu kekuasaan identik dengan dunia laki-laki. Apabila perempuan masuk ke panggung politik kerap dianggap sesuatu yang kurang lazim atau tidak pantas

\footnotetext{
26 Ikhwan Fauzi, Perempuan dan Kekuasaan..., h. 70.

27 Zubaedi, Islam dan Benturan Peradaban, (Yogyakarta: Ar-Ruzz Media, 2007), h. 224.

28 Djazimah Muqoddas, Kontroversi Hakim Perempuan...), h. 88.
}

bahkan arena politik dianggap dunia yang keras, sarat dengan persaingan bahkan terkesan sangat ambisius. $^{29}$

Menghadapi nilai budaya patriarki, lengkap dengan pemahaman bias gender tersebut tentunya tidak seperti membalikkan telapak tangan. Mengubah cara pandang dan pola pikir (mind set) masyarakat yang telah mendarah daging dan terpola pengkondisiannya pada benak pikirannya tidaklah mudah, memerlukan kerja keras yang tentunya harus dimulai dari penyadaran diri sendiri. Persoalannya adalah tidak banyak kaum perempuan berminat atau tertarik pada dunia politik; diawali dari pola penempatan yang telah dikotak-kotakkan dan stereotype, perempuan tepat dan pantasnya ada di ranah domestik, sebaliknya laki-laki ada di ranah publik.

Belum lagi dunia politik di asumsikan sebagai dunia maskulin (keras, kasar, rasional, kompetitif, menakutkan) sehingga pantasnya hanya dimiliki laki-laki. Sementara ranah domestik berwatak feminim, lemah, lembut, emosional, ngalah, nurut, halus, ramah; inilah fungsi dan tugas yang tepat dan cocok bagi perempuan; dia di rumah mengurus dan membereskan permasalahan di rumah tangga. ${ }^{30}$

\section{Mitos Kejadian Manusia}

29 Djazimah Muqoddas, Kontroversi Hakim Perempuan..., h. 93.

30 Djazimah Muqoddas, Kontroversi Hakim Perempuan..., h. 95. 
Di antara penyebab timpangnya hubungan laki-laki dan perempuan yang berujung pada ketidakadilan terhadap perempuan ini antara lain mitos-mitos yang disebarluaskan melalui nilai-nilai dan tafsirtafsir ajaran agama yang keliru mengenai keunggulan kaum laki-laki. Sebaliknya, tentang perempuan adalah mitos-mitos yang melemahkan kaum perempuan. Laki-laki selalu digambarkan sebagai makhluk yang cerdas, kuat, tidak emosional. Sementara perempuan adalah mahkluk yang lemah, bodoh, emosional dan tidak mandiri. ${ }^{31}$

Ada pandangan dasar yang menyebabkan munculnya ketidaksetaraan laki-laki dan perempuan berdasarkan cerita-cerita Israiliyat dalam agama Yahudi dan Kristen. Pertama, perempuan diyakini telah diciptakan dari tulang rusuk Adam, sehingga ia dianggap bukanlah yang utama tanpa kehadiran Adam. Keberadaan perempuan karenanya bersifat pelengkap dan dianggap ada hanya karena laki-laki dan untuk lakilaki. Sebaliknya, laki-lakilah yang dianggap sebagai ciptaan yang utama, karena ia diciptakan secara utuh, dan bukan berasal dari manusia lain. Kedua, perempuan diyakini sebagai sumber dari terusirnya manusia dari surga. Oleh sebab itu, selayaknyalah perempuan dipandang dengan

\footnotetext{
Ratna Batara Munti, Perempuan sebagai Kepala Rumah Tangga, (Jakarta: Lembaga Kajian Agama dan Gender, 1999), h. 37. 131
}

rasa benci, curiga dan jijik, bahkan lebih jauh sebagai sumber malapetaka. ${ }^{32}$

\section{Penutup}

Berdasarkan pembahasan yang telah dijabarkan mengenai kedudukan pemimpin perempuan dalam Islam, maka dapat disimpulkan sebagai berikut :

1. Kedudukan pemimpin perempuan dalam Islam sampai saat ini masih menuai pro dan kontra. Ada yang membolehkan perempuan menjadi pemimpin, sebaliknya ada juga yang tidak membolehkan. Akan tetapi mayoritas ulama lebih banyak yang tidak membolehkan.

2. Perbedaan pendapat mengenai pemimpin perempuan tersebut muncul karena beberapa faktor, baik karena faktor berbedanya penafsiran terhadap ayat alQuran dan Hadist, Ijma' dan Qiyas, maupun karena budaya patriarki yang belum hilang dari masyarakat, serta mitos-mitos kejadian manusia mengenai perempuan itu sendiri.

\section{Pustaka Acuan}

Al Mawardi. Al-Ahkam Al Sulthaniyah. (Beirut: Darul Fikr. $450 \mathrm{H}$ )

An-Nisaburi, Al-Wahidi. Asbabun Nuzul; sebab-sebab turunnya ayat-ayat alQur'an. (Surabaya: Amelia. 2014)

\footnotetext{
32 Ratna Batara Munti, Perempuan sebagai Kepala Rumah Tangga, (Jakarta: Lembaga Kajian Agama dan Gender, 1999), h. 41.
} 
AL-IMARAH: Jurnal Pemerintahan dan Politik Islam

Vol. 3, No. 1, 2018

Batara Munti, Ratna. Perempuan Sebagai Kepala Rumah Tangga. (Jakarta: Lembaga Kajian Agama dan Gender. 1999)

D. Aini, Ira, Milastri Muzakkar. Perempuan Pembelajar. (Jakarta: PT. Elex Media Komputindo. 2014)

Departemen Agama RI. Al-Qur'an dan Terjemahan. (Bandung : PT Syigma Examedia Arkanleema. 2010)

Fauzi, Ikhwan. Perempuan dan Kekuasaan;

Menelusuri Hak Politik dan

Persoalan Gender dalam Islam.

(Jakarta: Amzah. 2008)

Jamhari, Ismatu Ropi. Citra Perempuan dalam Islam. (Jakarta: Gramedia Pustaka Utama. 2003)

Mas'ud al-Baghawi, Abi Muhammad bin. Syarhus-Sunnah. (Darul Kitab 'Amaliyah. 436-516 H)

Muhammad, Abi bin Mas'ud al-Baghawi. Syarhus-Sunnah. (Darul Kitab 'Amaliyah. 436-516 H)

Muhanif, Ali. Perempuan dalam Literatur Islam Klasik. (Jakarta: Gramedia Pustaka Utama. 2003)

Muqoddas, Djazimah. Kontroversi Hakim Perempuan pada Peradilan Islam di Negara-negara Muslim.

(Yogyakarta : PT Lkis, 2011)

Qardhawy, Yusuf. Fatwa-fatwa Kontemporer Jilid 1\&2. (Jakarta: Gema Insani Press. 1999)
Qardhawy, Yusuf. Fiqh Negara. (Jakarta: Robbani Press. 1997)

Suprana, Jaya. Kelirumologi Genderisme. (Jakarta: Gramedia. 2014)

Syawkani, Imam. Naiul Awtar. (Darul hadis. 1426 H / 2005 M)

Tebba, Sudirman. Islam Pasca Orde Baru. (Yogyakarta, Tiara Wacana Yogya. 2001)

Wirawan. Kepemimpinan : Teori, Psikologi, Perilaku Organiasasi, Aplikasi dan Penelitian. (Jakarta: PT Rajagrafindo Persada. 2013)

Zubaedi. Islam dan Benturan Peradaban. (Yogyakarta: Ar-Ruzz Media. 2007) 